\title{
Survival rate of imPlasa dental implant system: long-term results
}

\author{
Karen Grigoryan ${ }^{1}$, Ruzanna Shahverdyan ${ }^{2}$
}

\section{Background}

${ }^{1}$ Yerevan State Medical University, Yerevan, Armenia, ${ }^{2}$ Avanta Innovative Medical Center, Yerevan, Armenia
The imPlasa Hoechst implant system is characterized by sand blasted and acid-etched surface, internal connection and self-tapping thread. They are manufactured from high-quality titanium alloy Ti6AI4V ELI. Milled titanium parts are blasted with wet alumina and titanium particles sized 25 $\mu \mathrm{m}$ and $75 \mu \mathrm{m}$. After the implants are etched using the immersion method for several minutes in a mixture of concentrated $\mathrm{HCl}$ and $\mathrm{H} 2 \mathrm{SO} 4$ heated above $100^{\circ} \mathrm{C}$ (dual acid etching). The dual acid-etched surface enhances the osteoconductive features through the attachment of fibrin and osteogenic cells, resulting in bone formation directly on the surface of implant. The dual acid-etched surface provides optimal surface charecteristics required for enhanced osseointegration. In 2012 we presented an analysis of imPlasa implants' survival rate in a short-term period. In February - March 2017 we did the analysis of imPlasa implants long-term survival rate involving the patients who had implants placed between May 2008 - March 2011. The results are provided in this paper.

\section{Aim}

The aim of the present study was to retrospectively evaluate the long-term survival rate of imPlasa implants.

\section{Methods and Materials}

637 implants were inserted in 127 patients between May 2008 and March 2011 in a private dental implant clinic. Associated factors, such as the patients characteristics, distribution of implants, survival rate, treatment type, were analyzed. The study excluded patients with a poor level of oral hygiene, with exacerbation of chronic periodontitis, decompensated diabetes and patients taking immunosuppressive drugs, undergoing radiation therapy. Each patient was given a full examination of the oral cavity and underwent X-ray imaging of the teeth. When necessary, in order to clarify the indications and careful treatment planning, CT scan was performed. The observations were carried out on a single protocol, which was formed by a database of patients, operations and results of examinations of the criteria for success of implant treatment according to Albrektsson et al. All patients have taken antibiotics and anti-inflammatory drugs immediately after implant placement. Treatment of a specified number of patients has been performed following a two-stage procedure. The placement of healing abutments started after 3 months on the lower jaw and 6 months on the upper jaw. In the cases of implant placement accompanied by open sinus membrane lifting surgery the osseointegration period was extended to 8 months. Fixed and removable provisional prostheses were made not earlier than 3 weeks after surgery. Removable prostheses were made as they do not press on the operated areas. Patients were advised to limit the usage of provisionals mainly to cosmetic purposes.

\section{Results}

1. Patient characteristics: 127 patients were treated with imPlasa implants. 2. The reason of tooth loss was periodontal problems $(67 \%)$, caries complications (7\%), tooth fractures (13\%) etc.

3. 37 patients were heavy smokers.

4. 43 sinus floor elevations were performed on 34 patients ( 23 open and 20 closed surgeries).

5. From the total number of treated patients 92 had implants placed on the maxilla and 82 on the mandible. 386 implants were placed in the anterior region, 251 implants in the posterior.

6 . The number of implants placed on the upper jaw was 314 .

7. The number of implants placed on the lower jaw was 323 .

8. The most commonly used implant diameters were $3.75 \mathrm{~mm}$ (278) and 4.2 $\mathrm{mm}$ (277).

\section{References}

1.Albrektsson T., Zarb G., Worthigton P., Eriksson A. The long-term efficacy of currently used dental implants: Review and proposed criteria of success. Int J Oral Maxillofac Implants 1986; 11-27

2.Tonetti M. Cigarette smoking and periodontal deseases: Etiology and management of desease. Ann Periodontal 1998; 3:88-101 3.Zarb G., Schmitt A., The longitudinal clinical effectivenee of osseointegrated dental implants. The Toronto Study. Part 1. Surgical results. J Prosthet Dent 1989; 63: 451-457

4. K.Grigoryan, Survival rate of imPlasa dental implant system. A retrospective study. Clinical Oral Implant Research, vol.23, supplement7, October 2012, page141
9. The most commonly used length was $13 \mathrm{~mm}$.

10. $25 \%$ of implants were restored by a single crown, $75 \%$ by bridge type fixed prostheses or overdentures.

11. 33 implants failed in 24 patients 8 of which were heavy smokers. 10 implants didn't osseointegrate. Eventually most of the lost implants were successfully replaced.

12. The greatest number of failed implants was observed in the area of teeth \#26, 36, 46 (12 cases) which was due to the poor bone quality.

13. All of the osseointegrated implants were subsequently loaded.

14. The overall survival rate for the long-term analysis was $94.8 \%$.

\section{Number of placed/failed implants by diameter}

\begin{tabular}{|c|c|c|c|c|c|c|}
\hline $\begin{array}{c}\text { Implants } \\
\text { diameter } \\
\text { in } \mathrm{mm}\end{array}$ & $\begin{array}{c}\text { Number } \\
\text { of } \\
\text { inserted } \\
\text { implants }\end{array}$ & $\begin{array}{c}\text { Percent } \\
\text { age of } \\
\text { inserted } \\
\text { implant } \\
\text { s } \%\end{array}$ & $\begin{array}{c}\text { Number } \\
\text { of failed } \\
\text { implants } \\
\text { short- } \\
\text { term }\end{array}$ & $\begin{array}{c}\text { Percent } \\
\text { age of } \\
\text { failed } \\
\text { implant } \\
\text { s } \\
\text { short- } \\
\text { term }\end{array}$ & $\begin{array}{c}\text { Number } \\
\text { of failed } \\
\text { implant } \\
\text { s } \\
\text { long- } \\
\text { term }\end{array}$ & $\begin{array}{c}\text { Percent } \\
\text { age of } \\
\text { failed } \\
\text { implant } \\
\text { s } \\
\text { long- } \\
\text { term }\end{array}$ \\
\hline 3.3 & 35 & $5.5 \%$ & 1 & $2.8 \%$ & 5 & $14.3 \%$ \\
\hline 3.75 & 278 & $43.6 \%$ & 6 & $2.2 \%$ & 15 & $5.4 \%$ \\
\hline 4.2 & 276 & $43.3 \%$ & 1 & $0.3 \%$ & 4 & $1.45 \%$ \\
\hline 5.0 & 47 & $7.4 \%$ & 5 & $10.6 \%$ & 9 & $19.2 \%$ \\
\hline 6.0 & 6 & $0.2 \%$ & - & - & - & - \\
\hline Total & 637 & $100 \%$ & 13 & $2.1 \%$ & 33 & $5.2 \%$ \\
\hline
\end{tabular}

\section{Number of placed/failed implants by length}

\begin{tabular}{|c|c|c|c|c|c|c|}
\hline $\begin{array}{l}\text { Implants } \\
\text { length in } \\
\text { mm }\end{array}$ & $\begin{array}{l}\text { Number } \\
\text { of } \\
\text { inserted } \\
\text { implants }\end{array}$ & $\begin{array}{c}\text { Percent } \\
\text { age of } \\
\text { inserted } \\
\text { implant } \\
5 \%\end{array}$ & $\begin{array}{c}\text { Number } \\
\text { of failed } \\
\text { implants } \\
\text { short- } \\
\text { term }\end{array}$ & $\begin{array}{c}\text { Percent } \\
\text { age of } \\
\text { failed } \\
\text { implant } \\
s \\
\text { short- } \\
\text { term }\end{array}$ & $\begin{array}{c}\text { Number } \\
\text { of } \\
\text { failed } \\
\text { implant } \\
s \\
\text { long- } \\
\text { term }\end{array}$ & $\begin{array}{c}\text { Percent } \\
\text { age of } \\
\text { failed } \\
\text { implant } \\
\text { s } \\
\text { long- } \\
\text { term }\end{array}$ \\
\hline 8 & 47 & $7.37 \%$ & - & - & 5 & $10.6 \%$ \\
\hline 10 & 130 & $20.4 \%$ & 3 & $2.3 \%$ & 6 & $4.6 \%$ \\
\hline 11.5 & 178 & $28 \%$ & 6 & $3.4 \%$ & 13 & $7.3 \%$ \\
\hline 13 & 202 & $31.7 \%$ & 3 & $1.5 \%$ & 7 & $3.5 \%$ \\
\hline 16 & 80 & $12.55 \%$ & 1 & $1.25 \%$ & 2 & $2 . \%$ \\
\hline Total & 637 & $100 \%$ & 13 & $2.1 \%$ & 33 & $5.2 \%$ \\
\hline
\end{tabular}

\section{Conclusions}

\section{The Survival Rate of ImPlasa dental Implant System}

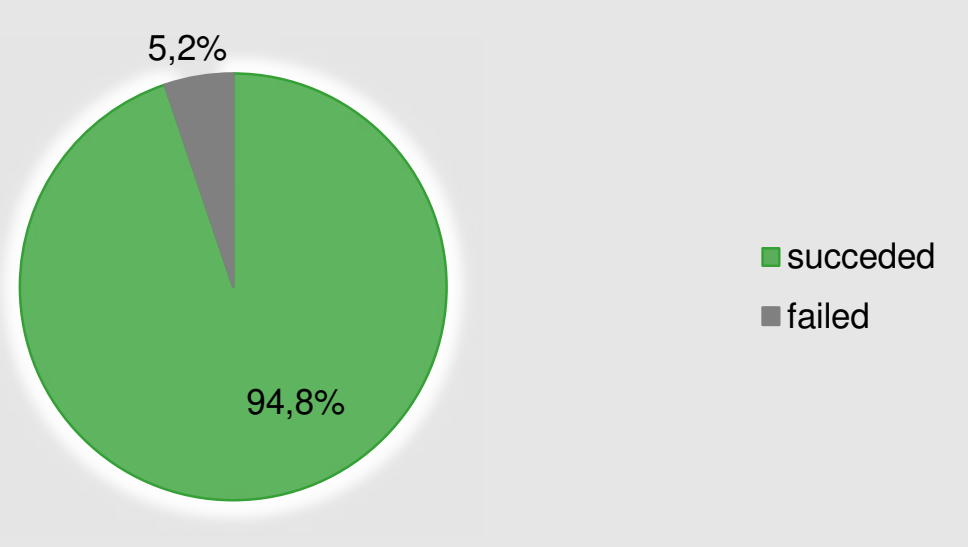

With survival rate of $94.8 \%$ ImPlasa dental implants showed excellent performance and predictability in this long-term retrospective study. 